\title{
Penerapan Metode Tebak Kata dalam Meningkatkan Pemahaman Siswa Belajar Peranan Politik Luar Negeri Indonesia Dalam Era Globalisasi
}

\author{
HIDAYATI \\ Sekolah Dasar Negeri 023 Pandau Jaya \\ Jln. AR. Rahim IV No. 1 Siak Hulu, Kampar \\ E-mail : hidayati@yahoo.com
}

\begin{abstract}
: teachers act as the manager of the learning process, develop teaching materials well, and improve the ability of students to listen to the lessons and master the educational goals they need to accomplish. Through the method of class actions implemented in SDN 023 Padau Jaya in grade social studies result observassi in cycle I-III illustrate the attitude of the students in following the lessons already provide a change in the behavior of pupils, especially in completing a given task, where students have been able to believed proved still late and has also been honest in completing tasks such as not cheating, but already showing civic attitude that is ready to give his devotion in implementing local togetherness. The application of the word tabak method can improve learning outcomes of civic education, especially in matter of understanding of the role of Indonesia's foreign policy in the era of globalization with the achievements of the KKM and attitudes pupil behavior.
\end{abstract}

Keywords: method of charades, understanding learning

Metode mengajar yang guru gunakan dalam setiap kali pertemuan di kelas bukanlah asal pakai, tetapi setelah melalui seleksi yang berkesesuaian dengan perumusan tujuan instruksional khusus.Jarang sekali guru merumuskan tujuan hanya dengan satu rumusan, tetapi pasti guru merumuskan lebih dari satu tujuan.Oleh sebab itu gurupun menggunakan metode yang lebih dari satu.(Masjoko, 2015)

Materi pelajaran yang akan disampaikan tanpa memperhatikan pemakaian metode justru akan mempersulit guru dalam mencapai tujuan pembelajaran.pengalaman membuktikan bahwa kegagalan pengajaran salah satunya disebabkan oleh pemilihan metode yang kurang tepat. Hal ini sama seperti yang dijelaskan Syaiful bahwa kelas yang kurang bergairah dengan kondisi peserta didik yang kurang kreatif dikarenakan penentuan metode yang kurang sesuai dengan sifat bahan dan tidak sesuai dengan tujuan pengajaran. (Masjoko, 2015)

Dengan demikian dapat dipahami bahwa metode adalah suatu cara yang memiliki nilai strategis dalam kegiatan belajar mengajar. Nilai strategisnya adalah metode dapat mempengaruhi jalannya belajar. Karena itu guru sebaiknya memperhatikan dalam pemilihan dan penentuan metode metode sebelum mengajar di kelas.(Masjoko, 2015)

Ketika peserta didik tidak mampu berkonsentrasi, ketika sebagian besar peserta didik mebuat kegaduhan, ketika peserta didik menunjukan kelesuan, ketika minat belajar peserta didik berkurang dan sebagian besar peserta didik tidak menguasai materi yang telah guru sampaikan, ketika itulah perlu dipertanyakan factor penyebabnya dan usaha mencari jawaban secara tepat. Apa bila hal itu tidak dilakukan maka guru akan mengajar dengan sia-sia. Boleh jadi dari berbagai keadaan tersebut salah satu pnyebabnya adalah factor metode.Karena hal itu, efektifitas penggunaan metode perlu dipertanyakan. (Masjoko, 2015)

Metode tebak kata adalah adalah metode pembelajaran yang dilakukan secara berpasangan dengan cara siswa menebak jawaban dari pertanyaan yang 
diberikan oleh pasangannya. Pertanyaan dan jawaban tertera dalam kartu. Kartu pertanyaan berisi ciri-ciri atau kata-kata lainnnya yang mengarah pada jawaban (istilah) yang mau ditebak. Sedangkan kartu jawaban berisi kata-kata atu istilah yang mau ditebak. Hamzah Uno dalam (Hasanah, 2016)

Salah satu sikap yang harus ditanamkan kepada siswa yaitu sikap berani untuk tampil didepan umum. Sikap berani dapat dilatih dalam proses pembelajaran IPS, contohnya ketika mempresentasikan hasil diskusi didepan kelas. Pengamatan yang dilakukan oleh peneliti dalam suatu kelas, dalam kegiatan presentasi hasil diskusi, perwakilan kelompok akan maju ke depan kelas. Siswa saling menunjuk temannya ketika guru memerintahkan perwakilan kelompok maju ke depan. Siswa yang tidak mau maju terpaksa harus maju karena semua temannya menyuruh untuk maju. (Hasanah, 2016)

Permasalahan yang dihadapi guru mata pelajaran pendidikan kewarganegaraan di SD N 023 Pandau Jaya kelas VI PKN II semester genap adalah pada sub materi peranan politik luar negeri Indonesia dalam era globalisasi, sesuai dengan kompetensi dasarnya menjelaskan berbagai peranan politik luar negeri Indonesia dalam era globalisasi. Dari data tersebut di atas jelas dapat diketahui ketuntasan murid yang rendah. Sedangkan sisanya masih belum tuntas dan persoalan ini menjadi masalah karena standar pencapaian ketuntasan yang diharapkan adalah 80 dari murid di kelas. Selama ini metode pembelajaran yang digunakan adalah metode ceramah dan tanya jawab, pada kesempatan ini penulis mencoba menggunakan metode tebak kata.

Menurut Dimyati dan Mudjiono hasil belajar merupakan hasil dari suatu interaksi tindak belajar mengajar. Materi pendidikan kewarganegaraan salah satu materi yang memerlukan pemahaman yang kuat guna untuk membentuk dan membina watak yang baik. Sehingga perlu menggunakan pemilihan metode yang aktif

Jurnal Daya Saing dan pemahaman yang jelas. (Paramita, 2012)

Menurut Edi Purnomo (2013) metode pembeljaran tebak kata merupakan penyampaian materi ajar dengan menggunakan kata-kata singkat dalam bentuk kartu permainan sehingga anak dapat menerima pesan pembelajaran melalui kartu itu. Untuk itu, buatlah kartu yang didalamnya mengandung berbagai pertanyaan yang membutuhkan satu karta jawaban yang dapat mewakili dari seluruh pertanyaan atau pernyaan yang ada. Dengan demikian menebak kata merupakan aktivitas pembelajaran yang pertama dan utama dalam mewujudkan keberhasilan proses belajar mengajar. Melalui tebak kata, murid diarahkan untuk memahami dan mengetahui pesanpesan yang terkandung dalam amteri.

Jadi dengan mampunya murid menebak kata berarti mencerminkan kemampuan murid dalam menguasai dan memahami materi yang ada.

Langkah-langkah Model Pembelajaran Tebak Kata:

1. Guru mempersiapkan kartu yang akan digunakan dalam proses pembelajaran.

2. Guru menjelaskan kompetensi yang ingin dicapai atau materi pelajaran selama \pm 45 menit.

3. Guru menyusun peserta didik berdiri berpasangan didepan kelas.

4. Seorang peserta didik diberi kartu yang berukuran $10 \times 10 \mathrm{~cm}$ yang nantinya dibacakan kepada pasanganya. Seorang peserta didik lainnya diberikan kartu dengan ukuran $5 \times 2 \mathrm{~cm}$ yang isinya tidak boleh dibaca (kertasnya dilipat) kemudian ditempelkan di dahi atau diselipkan ditelinga (dengan syarat murid yang memegang kartu yang berukuran 10x10 $\mathrm{cm}$ bisa melihat apa jawabannya).

5. Peserta didik yang memegang kartu 10x10 cm membacakan katakata yang tertulis didalamnya sementara pasanganya menebak

p.ISSN: $2407-800 X \quad$ e.ISSN: $2541-4356$ 
apa yang dimaksud dalam kartu $10 \times 10 \mathrm{~cm}$. Jawaban tepat apabila sesuai isi kartu yang berukuran $5 \times 2$ cm tersebut.

6. Apabila jawabanya tepat (sesuai yang tertulis dikartu) maka pasangan itu boleh duduk. Bila belum tepat pada waktu yang ditetapkan, peserta didik boleh mengarahkan dengan kata-kata lain, dengan syarat tidak langsung memberikan jawabannya.

7. Pengambilan kesimpulan.

8. Penutup.

\section{METODE}

Prosedur penelitian tindakan kelas ini merujuk pada model Kurt Lewin yang terdiri atas empat komponen pokok penelitian kelas yakni: 1) perencanaan (planning), 2) tindakan (acting), 3) pengamatan (observing), dan 4) refleksi (reflecting).

Action research is a form of selfreflective enquiry undertaken by participants (teachers, students or principals, for example) in social (including educational) situations in order to improve the rationality and justice of (1) their own social or educational practices, (2) their understanding of these practices, and (3) the situations (and institutions) in which the practices are carried out. Jika kita cermati pengertian tersebut secara saksama, kita akan menemukan sejumlah ide pokok sebagai berikut. 1. Penelitian tindakan adalah satu bentuk inkuiri atau penyelidikan yang dilakukan melalui refleksi diri. 2. Penelitian tindakan dilakukan oleh peserta yang terlibat dalam situasi yang diteliti, seperti guru, siswa, atau kepala sekolah.3. Penelitian tindakan dilakukan dalam situasi sosial, termasuk situasi pendidikan. 4. Tujuan penelitian tindakan adalah memperbaiki: dasar pemikiran dan kepantasan dari praktikpraktik, pemah- aman terhadap praktik tersebut, serta situasi atau lembaga tempat praktik tersebut dilaksanakan.(Wardani, 2012)
Analisis data dalam penelitian tindakan kelas ini menggunakan analisis kuantitatif dan kualitatif. Hasil perhitungan dikonsultasikan dengan tabel kriteria deskriptif prosentase, yang dikelompokkan dalam 3 kategori, yaitu baik, cukup, kurang. Hasil observasi dianalisis menggunakan teknik deskriptif kualitatif yang digambarkan dengan kata-kata atau kalimat, dipisah-pisahkan menurut kategori untuk memperoleh kesimpulan.

\section{HASIL}

Telah diketahui bahwa subjek penelitian berjumlah 26 murid. Pelaksanaan penelitian tindakan kelas ini dilakukan dalam 3 (tiga) siklus, yakni siklus I. Berikut disajikan paparan hasil penelitian yang terdiri atas hasil belajar PKN melalui kolaborasi model pembelajaran tebak kata dan hasil observasi terhadap proses pembelajaran.

Gambar 1: Hasil belajar per siklus

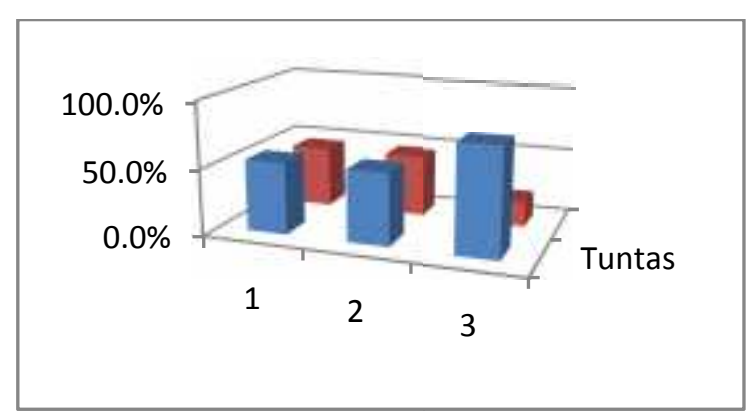

Berdasarkan data hasil penelitian siklus I mengenai hasil belajar PKN materi pokok menjelaskan pengertian dan mengidentifikasi peranan politik luar negeri Indonesia dalam era globalisasi, melalui model pembelajaran tebak kata diperoleh data untuk ketuntasan 80 sebanyak 61,5 tidak tuntas.

Hasil penelitian siklus I mengenai hasil belajar PKN materi pokok yang sama mengenai system pemerintahan, melalui model pembelajaran tebak kata diperoleh data untuk ketuntasan 80 sebanyak $61,5 \%$ tuntas. dan rata-rata hasil belajar sebesar 79 . 
Pada siklus III mengenai hasil belajar PKN materi pokok yang sama namun dengan bahasan memahami system yang ada, melalui model pembelajaran tebak kata diperoleh data untuk ketuntasan 80 sebanyak $57,7 \%$. dan rata-rata hasil belajar sebesar 85 .

\section{PEMBAHASAN}

Perolehan hasil belajar melalui metode tebak kata Siklus I-III ketuntasan individual baru mencapai 57,7\%. Potret pembelajaran PKN sudah mencapai tujuan yang diharapkan guru yang tertuang dalam indikator kinerja dari jumlah murid dalam kelas telah mencapai ketuntasan belajar individual, sehingga sudah perlu dapat diakhiri penelitian ini dan terus mengalami peningkatan.

Data pada siklus I-III diperoleh gambaran tentang sikap para murid dalam mengikuti pelajaran sudah memberikan perubahan pada perilaku murid khususnya dalam menyelesaikan tugas yang diberikan, dimana murid sudah dapat dipercaya terbukti masih terlambat dan juga sudah jujur dalam menyelesaikan tugas seperti tidak mencontek namun sudah menunjukkan sikap kewarganegaraan yang siap memberikan baktinya dalam melaksanakan kebersamaan dalam lokal.

Hasil penelitian ini sejalan dengan penelitian Pramukti, bahwa pada tes awal diperoleh tingkat ketuntasan hasil belajar siswa secara klasikal yaitu 3 orang siswa $(10,71 \%)$. Setelah pelaksanaan siklus I, diperoleh tingkat ketuntasan hasil belajar siswa secara klasikal yaitu 12 orang siswa $(42,85 \%)$. Selanjutnya pada siklus II, diperoleh tingkat ketuntasan hasil belajar siswa lebih meningkat yaitu sebanyak 25 orang siswa $(89,29 \%)$. Berdasarkan temuan dari hasil penelitian dapat disimpulkan bahwa model pembelajaran Tebak Kata dapat meningkatkan hasil belajar siswa pada mata pelajaran PKN materi sistem pemerintahan pusat kelas IV SDN 101789 Marindal T.A. 2015/2016. (Pramukti, 2016)

Juga hasil penelitian Setyowati yang mengatakan bahwa penerapan model kooperatif tipe tebak kata pada mata Jurnal Daya Saing pelajaran IPS setelah melaui langkahlangkah kegiatan awal, inti dan juga akhir menunjukkan adanya peningkatan hasil belajar siswa kelas V MI Himmatul Ulum Gandusari Trenggalek. Data dari siklus I menunjukkan nilai rata-rata hasil belajar siswa secara keseluruhan adalah 80 dengan prosentase ketuntasan $63,63 \%$. Sedangkan pada siklus II rata-rata hasil belajar siswa menjadi 90 dengan ketuntasan belajar siswa keseluruhan adalah 86,36\%.(Setyowati, 2015)

Ratna menjelaskan tingkat Pemahaman dan Keaktifan siswa sebelum tindakan masih rendah. Hal ini ditunjukkan dengan jumlah siswa atau prosentasi tingkat pemahaman siswa yang terbagi menjadi tiga tingkatan memiliki prosentasi yang rendah, yaitu dari tingkat terendah sekitar $27,78 \%$ atau sekitar 10 siswa, tingkat sedang sekitar $50 \%$ atau 18 siswa, dan tingkat tertinggi sekitar $22,22 \%$ atau 8 siswa dari total 36 siswa, sedangkan prosentasi siswa yang aktif dan merespon pelajaran guru, yaitu sekitar $36,12 \%$ atau 13 siswa yang aktif dan sekitar $44,45 \%$ atau 16 siswa yang merespon.. Setelah pelaksanaan siklus I prosentase untuk tingkat pemahaman dari tingkat terendah siswa turun menjadi 16,67\% atau sekitar 6 siswa, tingkat sedang naik menjadi 55,56\% atau sekitar 20 siswa dan tingkat tertinggi naik menjadi $27,78 \%$ atau sekitar 10 siswa, sedangkan peningkatan keaktifan naik menjadi 63,88\% atau sekitar 23 siswa dari KKM yang ditetapkan yaitu $\leq 60$, peningkatan respon siswa naik menjadi $55,55 \%$ atau sekitar 20 siswa.. Pada siklus II, dapat diketahui bahwa untuk tingkat pemahaman juga telah mengalami banyak kemajuan, yaitu untuk tingkat terendah turun menjadi $8,33 \%$ atau hanya tinggal 3 anak, tingkat sedang mengalami kenaikan menjadi 63,88\% atau menjadi 23 anak, dan tingkat tertinggi tidak mengalami peningkatan atau tetap 10 anak atau $27,78 \%$, sedangkan $91,67 \%$ atau sekitar 33 anak telah mengalami peningkatan keaktifan dalam kegiatan pembelajaran, baik aktif secara individu maupun p.ISSN: $2407-800 X \quad$ e.ISSN: $2541-4356$ 
kelompok, tingkat respon terhadap pelajaran yang diberikan guru pun telah meningkat sebanyak 97,22\% atau sekitar 35 anak. (Ratna Dewi Saputri, 2012)

\section{SIMPULAN}

Penerapan metode tabak kata dapat meningkatkan hasil belajar pendidikan kewarganegaraan khususnya pada materi pemahaman terhadap Peranan politik luar negeri Indonesia dalam era globalisasi dengan capaian nilai KKM dan sikap perilaku murid sebagai warganegara.

Serta dijelaskan oleh Hasanah bahwa metode tebak kata dapat meningkatkan hasil belajar IPS dengan cara waktu pemahaman materi dibatasi; pembagian kelompok sesuai dengan karakteristik siswa; kata-kata dalam kartu pertanyaan dari khusus ke umum; urutan maju tidak ditentukan lebih awal; siswa yang tidak maju diberi kesempatan untuk menebak jawaban; menggunakan kompetisi. Hal ini dapat ditunjukkan melalui hasil tes yaitu 18 siswa yang mendapatkan nilai $\geq 75$ di siklus I meningkat menjadi 27 siswa di siklus II, ranah afektif dan psikomotorik mengalami peningkatan dari "baik" di siklus I menjadi "sangat baik" di siklus II (Hasanah, 2016)

\section{DAFTAR RUJUKAN}

Edi Purnomo, 2013, Model Pembelajaran Tebak Kata, etc, Jakarta.

Hasanah, n. (2016). Peningkatan hasil belajar ips melalui metode tebak kata. Jurnal pendidikan guru sekolah dasar, 16(5), 551-559.

Masjoko. (2015). Metode_belajar_mengajar.

Paramita, a. (2012). Peningkatan hasil belajar pkn melalui metode artikulasi pada siswa kelas $\mathrm{v}$ sd negeri 2 borongan polanharjo klaten tahun ajaran 2011/ 2012. Skripsi, 0-13.

Pramukti, a. S. (2016). Penggunaan Model Pembelajaran Tebak Kata untuk
Meningkatkan Hasil Belajar Siswa pada Mata Pelajaran PKn Kelas IV SD Negeri 101789 Marindal Tahun Ajaran 2015/2016., 101789.

ratna dewi saputri. (2012). penerapan metode tebak kata untuk meningkatkan pemahaman dan keaktifan siswa kelas $\mathrm{v}$ terhadap mata pelajaran ipa (di sekolah dasar negeri 1 sawahan tahun ajaran 2011/2012).

Setyowati, E. T. (2015). "Penerapan Model Kooperatif Tipe Tebak Kata untuk Meningkatkan Hasil Belajar IPS Siswa Kelas V MI Himmatul Ulum Gandusari Trenggalek, 90.

Wardani, K. (2012). hakikat penelitian tindakan kelas, 1-36. 